\title{
Correlation of Clinical Symptoms of Gastritis with H. pylori Occurrence in Children
}

\author{
Nur'atmi Gusti Dewi ${ }^{\mathrm{a}}$, Supriatmo ${ }^{\mathrm{b}}$, Karina Sugih Arto $^{\mathrm{c}}$, Isti Ilmiati Fujiatid, \\ Rina Amalia C Saragih ${ }^{\mathrm{e}}$, Rizky Adriansyah ${ }^{\mathrm{f}}$ \\ adewibusra01@gmail.com \\ ${ }^{a}$ Resident of Paediatrics, School of Medicine, University of North Sumatera, Medan, Indonesia \\ ${ }^{b}$ Department of Paediatric, School of Medicine, University of North Sumatera, Medan, Indonesia \\ ${ }^{c}$ Department of Paediatrics, School of Medicine, University of North Sumatera, Medan, Indonesia \\ ${ }^{d}$ Department of Community Medicine, School of Medicine, University of North Sumatera, Medan, Indonesia \\ ${ }^{e}$ Department of Paediatric, School of Medicine, University of North Sumatera, Medan, Indonesia \\ ${ }^{f}$ Department of Paediatrics, School of Medicine, University of North Sumatera, Medan, Indonesia
}

\begin{abstract}
Background: H. pylori (H. pylori) infection is a problem worldwide, which is the most common cause of chronic gastritis, and it is strongly associated with gastric ulcer disease and gastric cancer. $H$. pylori cause gastritis in infected children with unspecified clinical manifestation and continue having non-specific symptoms along with their life. Currently, not many studies have examined specific clinical symptoms in gastritis caused by $H$. pylori.

Objective: To determine the correlation between clinical gastritis symptoms with $H$. pylori occurrence in children.

Method: A Cross-Sectional study in 2-18 years old patients with clinical symptoms of gastritis who came to the outpatient clinic and treated at H. Adam Malik General Hospital Medan and Educational Network Hospital from December 2019 to May 2020. Patients with clinical symptoms of gastritis got the endoscopic procedure and Campylobacter-like organism (CLO) test.

Result: 84 subjects were analyzed with 45 positive $H$. pylori and 39 negative $H$. pylori. There were no significant clinical symptoms differences between the $H$. pylori (+) group and the $H$. pylori (-) group. The most clinical symptom was recurrent abdominal pain, 26 patients $(57.8 \%)$ in the $H$. pylori group $(+)$ and 24 patients $(61.5 \%)$ in the $H$. pylori group (-) (p-value $=0.726)$, vomiting 12 patients $(26.7 \%)$ in the $H$. pylori group $(+)$ and 5 patients $(12.8 \%)$ in the $H$. pylori group $(-)$ with p-value $=0.115$, haematemesis in 6 patients $(13.3 \%)$ in the group $H$. pylori $(+)$ and 7 patients $(17.9 \%)$ in the $H$. pylori $(-)$ group $(\mathrm{p}$-value $=0.560)$ the least clinical symptoms were nausea in 1 patient $(2.2 \%)$ in the $H$. pylori group $(+)$ and 3 patients $(7.7 \%)$ in the H. pylori (-) group with a p-value $=0.333$

Conclusion: There is no significant correlation between clinical symptoms of gastritis and the occurrence of H. pylori infection in children.
\end{abstract}

Keywords: Clinical symptoms of gastritis, H. pylori, children

\section{Background}

Warren and Marshall found a new kind of bacteria in the stomachs of people with gastritis called Helicobacter pylori and found its role in chronic gastritis and peptic ulcer disease. ${ }^{1}$ Moreover, severe atrophic gastritis, accompanying intestinal metaplasia caused by persistent $H$. pylori infection, is closely related to gastric cancer development. ${ }^{2} \mathrm{H}$. pylori infection is a common, usually lifelong, infection and found worldwide, with infection rates vary according to geographic region, but the number of infected people has persisted or even increased over the past three decades because of population growth and because of reinfection and recrudescence due to unsuccessful eradication. ${ }^{3}$ Infection of $\mathrm{H}$. pylori is a health problem because it can cause bleeding, ulcers, and gastric cancer while in children H. pylori can cause gastritis with non-specific clinical manifestations and continue to have non-specific symptoms throughout their life. ${ }^{1}$

Approximately $80 \%$ of $\mathrm{H}$. pylori infection occurs in children below 10 years old, which is found $10 \%$ in a developed country and $50 \%$ of the cases in developed country living in scant socioeconomic status. Generally, H. pylori infection does not have typical symptoms, and only $10 \%-15 \%$ will cause several diseases, such as gastritis, peptic ulcer and in the long term can cause gastric adenocarcinoma and mucosa-associated lymphoid tissue (MALT) lymphoma, iron deficiency anemia, can even cause growth disturbances. ${ }^{4}$ In Indonesia, the prevalence of $H$. pylori infection vary: In Makassar 55\%, Solo 51.8\%, Yogyakarta 30.6\%, Surabaya 23.5\%, Bali $43 \%$, and the lowest found in Jakarta $8 \%$ and this vary prevalence was influenced by socioeconomic status and host-agent-environment factor. ${ }^{5}$ 
Gastritis is an inflammatory process in the gaster caused by an irritation or infection in the mucosa or submucosa and the most common gastrointestinal problems encountered in clinics because the diagnosis is based on clinical symptoms only not by the histopathological procedure. ${ }^{6}$ Gastritis is often considered a trivial thing, but gastritis can be the beginning of a disease that can interfere with a person's quality of life. The clinical symptoms of gastritis due to $\mathrm{H}$. pylori infection include recurrent abdominal pain, nausea, vomiting, hematemesis, burning sensation epigastrial region, and Gastroesophageal Reflux Disease (GERD). ${ }^{7-8}$ Studies have examined specific clinical symptoms in gastritis caused by $H$. pylori rarely found in Indonesia, so the author is interested in investigating the specific clinical symptoms in gastritis caused by $H$. pylori.

\section{Method}

The study was conducted at Gastroenterology Policlinic and Ward H. Adam Malik Medan Hospital, University of North Sumatera Hospital, and Columbia Asia Hospital Medan in December 2019 - May 2020. This is a prospective cross sectional study. With inclusion criteria: children $2-18$ years old with suspected $\mathrm{H}$. pylori infection with clinical manifestation recurrent abdominal pain, nausea, vomitus, and hematemesis, children who untaken medicine: Proton Pump Inhibitor (PPI), antibiotic and non-steroid anti-inflammatory drugs (NSAID) 1 month before the study, and had established with H. pylori diagnosis from the endoscopy with or without positivity of CLO test. Patients with metabolic diseases, liver diseases, renal diseases, inflammatory bowel diseases (IBD) and refuse endoscopic procedure are excluded. The subject who fulfil inclusion criteria will be informed about the study and will be fulfilling a questionnaire. The subjects will be done endoscopic and CLO test assessment (figure 1). The data will be analyzed using chi-square, Mann Whitney, Independent-T test, Kruskal Wallis, and Fischer Exact with SpSS v.20. Categoric data will be shown in frequency and percent while numeric data will be shown in mean \pm standard deviation (SD). P-value significant if $<0.05$.

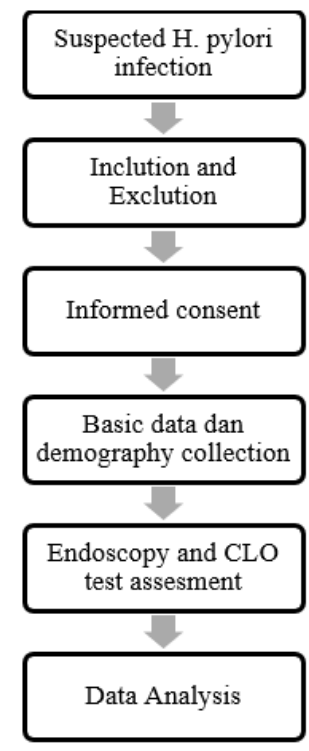

Figure 1. Subject recruitment

\section{Result}

From this study, we found a total of 84 children that meet the inclusion and exclusion criteria and from the endoscopy and CLO test, we found 45 children with $\mathrm{H}$. pylori-positive and 39 children with H. pylorinegative. Female $66.7 \%$ with mean age 12.97 years old, body weight mean $33.78 \mathrm{kgs}$ and body height mean $138.52 \mathrm{cms}$. From this study, we found the majority ethnic was Bataknese; the educational level majority was primary school, $35.7 \%$ (table 1). From the educational level, the majority of both father and mother was a college with $82.1 \%$ and $91.7 \%$. In contrast, most of both father and mother were private employees at the occupational level, with good socioeconomic status of $86.9 \%$ (table 2). 
Table 1. Subject Characteristic Study

\begin{tabular}{lc}
\hline Subject Characteristic & $\mathbf{n}=84$ \\
\hline Gender, $\mathrm{n}(\%)$ & $28(33,3)$ \\
Male & $56(66,7)$ \\
Female & \\
Age, $\mathrm{n}(\%)$ & 12,97 \\
$\quad$ Mean & \\
Body weight, kg & 37,78 \\
$\quad$ Mean & \\
Body height, $\mathrm{cm}$ & 138,52 \\
Mean & \\
Ethnic, $\mathrm{n}(\%)$ & $10(11,9)$ \\
$\quad$ Acehnese & $34(40,5)$ \\
Bataknese & $1(1,2)$ \\
India & $10(11,9)$ \\
Javanese & $13(15,5)$ \\
Melayunese & $10(11,9)$ \\
Minangnese & $2(2,4)$ \\
Papuanese & $4(4,8)$ \\
Chinese & \\
Child educational level, $\mathrm{n}(\%)$ & $5(6)$ \\
Kindergarten & $30(35,7)$ \\
Primary school & $22(26,2)$ \\
Secondary school & $20(23,8)$ \\
Senior high school &
\end{tabular}

Table 2. Parents Characteristic Subject Study

\begin{tabular}{lc}
\hline Parents Characteristic & $\mathrm{n}=84$ \\
\hline Father educational level, $\mathrm{n}(\%)$ & \\
$\quad$ Senior high school & $15(17,9)$ \\
College & $69(82,1)$ \\
Mother educational level, $\mathrm{n}(\%)$ & \\
Senior high school & $7(8,3)$ \\
College & $77(91,7)$ \\
Father's occupation, $\mathrm{n}(\%)$ & \\
Private employee & $42(50)$ \\
Farmer & $5(6)$ \\
Government employee & $11(13,1)$ \\
Army/ police & $5(6)$ \\
Entrepreneur & $21(25)$ \\
Mother's occupation, $\mathrm{n}(\%)$ & \\
Private employee & $31(36,9)$ \\
Farmer & $7(8,3)$ \\
Government employee & $14(16,7)$ \\
Entrepreneur & $19(22,6)$ \\
Housewife & $13(15,5)$ \\
Socioeconomic status, $\mathrm{n}(\%)$ & \\
Scant & $11(13,1)$ \\
Good & $73(86,9)$ \\
\hline & \\
\hline & \\
\hline & \\
\hline &
\end{tabular}


Table 3 shows the characteristic subject base on the positivity of H. pylori. We found 45 children positive H. pylori with most girls $(71.1 \%)$, while 39 children in negative H. pylori with most girls $(61.5 \%)$. We analyze with chi-square, and we found no different significant proportion between the gender of two groups with $\mathrm{p}=$ 0.353 . The mean age in group 1 was 11.79 years old, while in group 2 was 12.19 years old, and with the Mann Whitney test we found no significant age difference between the two groups $(p=0.594)$. Mean body weight and body height in positive $\mathrm{H}$. pylori was $37.89 \mathrm{~kg}$ and $137.89 \mathrm{~cm}$, while in negative $\mathrm{H}$. pylori was $37.66 \mathrm{~kg}$ and $139.26 \mathrm{~cm}$. We found no significant difference between mean body weight and mean body height both in the two groups $(p>0.05$ ). In ethnic, we found Bataknese was dominant in $H$. pylori-positive group and negative group with $45.5 \%$ and $38.9 \%$. We analyzed with Kruskal Wallis and found there are no significant differences between the two groups. In socioeconomic the good status was found in both of the two groups $84.4 \%$ and $89.7 \%$, analyzed with Chi-square we found no significant differences between the two groups. In children educational level both in group H. pylori-positive and negative were primary school and when we analyzed with Kruskal Wallis we also found no significant differences with $\mathrm{p}=0.893$.

Table 3. Characteristic Study base on H. pylori infection

\begin{tabular}{|c|c|c|c|}
\hline \multirow{2}{*}{ Subject Characteristic } & \multicolumn{2}{|c|}{ H. pylori } & \multirow{2}{*}{$\mathbf{P}$} \\
\hline & $(+) n=45$ & $(-) n=39$ & \\
\hline \multicolumn{4}{|l|}{ Gender, $n(\%)$} \\
\hline Male & $13(28,9)$ & $15(38,5)$ & $0,353^{a}$ \\
\hline Female & $32(71,1)$ & $24(61,5)$ & \\
\hline Age, Mean (SD), year & $11,79(3,87)$ & $12,19(3,46)$ & $0,594^{b}$ \\
\hline Body height, Mean (SD), kg & $37,89(15,67)$ & $37,66(11,79)$ & $0,942^{\circ}$ \\
\hline Body height, Mean (SD), cm & $137,89(20,59)$ & $139,26(17,68)$ & $0,829^{4}$ \\
\hline \multicolumn{4}{|l|}{ Ethnic, $n(\%)$} \\
\hline Acehnese & $6(13,6)$ & $4(11,1)$ & $0,485^{d}$ \\
\hline Batalknese & $20(45,5)$ & $14(38,9)$ & \\
\hline India & $1(2,3)$ & 0 & \\
\hline Javanese & $6(13,6)$ & $4(11,1)$ & \\
\hline Melayunese & $5(11,4)$ & $8(22,2)$ & \\
\hline Minangnese & $4(9,1)$ & $6(16,7)$ & \\
\hline Papuanese & $2(100)$ & 0 & \\
\hline Chinese & $1(2,2)$ & $3(7,7)$ & \\
\hline \multicolumn{4}{|l|}{ Socioeconomic status, $\mathrm{n}(\%)$} \\
\hline Scant & $7(15,6)$ & $4(10,3)$ & $0,473^{a}$ \\
\hline Good & $38(84,4)$ & $35(89,7)$ & \\
\hline \multicolumn{4}{|l|}{ Child educational level, $\mathrm{n}(\%)$} \\
\hline Kindergarten & $2(4,4)$ & $3(7,7)$ & $0,893^{4}$ \\
\hline Primary school & $18(40)$ & $12(30,8)$ & \\
\hline Secondary school & $11(24,4)$ & $11(28,2)$ & \\
\hline Senior high school & $10(22,2)$ & $10(25,6)$ & \\
\hline
\end{tabular}

In table 4 we found that the majority of educational status father and mother both in the two groups were college and we analyzed with Chi-square we found no significant differences between the parents' educational status ( $p>0.05$ ). Table 5 shows that recurrent abdominal pain is the most clinical manifestation felt by $59.5 \%$ children, while vomitus $20.2 \%$, haematemesis $15.5 \%$ and nausea $4.8 \%$.

In table 6 show that $2.2 \%$ child felt nausea in group 1 while in group $27.7 \%$, when we analyzed with Fischer exact test, we found there are no significant differences between two groups with $\mathrm{p}=0.333$. Vomitus found in $26.7 \%$ children in group 1 and $12.8 \%$ found in group 2, when we analyzed with Chi-square, we found no significant differences between two groups with $\mathrm{p}=0.115$. Hematemesis was found in $13.3 \%$ in group 1 and $17.9 \%$ found in group two, and we analyzed with Chi-square we found no difference significant between two groups with $\mathrm{p}=0.560$. Recurrent abdominal pain was felt by $57.8 \%$ children in group 1 and $61.5 \%$ children in group 2 and when we analyzed with Chi-square, we also found there are no significant differences between in the two groups with $\mathrm{p}=0.726$. 
Table 4. Parents Characteristic Study base on H. pylori infection

\begin{tabular}{|c|c|c|c|}
\hline \multirow{2}{*}{ Subject Characteristic } & \multicolumn{2}{|c|}{ H. pylori } & \multirow{2}{*}{$\mathbf{P}$} \\
\hline & $(+) n=45$ & $(-) n=39$ & \\
\hline \multicolumn{4}{|l|}{ Father educational level, $\mathrm{n}(\%)$} \\
\hline Senior high school & $8(17,8)$ & $7(17,9)$ & $0,984^{a}$ \\
\hline College & $37(82,2)$ & $32(82,1)$ & \\
\hline \multicolumn{4}{|l|}{ Mother educational level, $\mathrm{n}(\%)$} \\
\hline Senior high school & $5(11,1)$ & $2(5,1)$ & $0,442^{\mathrm{e}}$ \\
\hline College & $40(88,9)$ & $37(94,9)$ & \\
\hline \multicolumn{4}{|l|}{ Father's occupation, n (\%) } \\
\hline Private employee & $21(46,7)$ & $21(53,8)$ & \\
\hline Farmer & $4(8,9)$ & $1(2,6)$ & \\
\hline Government employee & $6(13,3)$ & $5(12,8)$ & \\
\hline Army/ police & $2(4,4)$ & $3(7,7)$ & \\
\hline Entrepreneur & $12(26,7)$ & $9(23,1)$ & \\
\hline \multicolumn{4}{|l|}{ Mother's occupation, $n(\%)$} \\
\hline Private employee & $14(31,1)$ & $17(43,6)$ & $0,187^{\mathrm{a}}$ \\
\hline Farmer & $6(13,3)$ & $1(2,6)$ & \\
\hline Government employee & $10(22,2)$ & $4(10,3)$ & \\
\hline Entrepreneur & $9(20)$ & $10(25,6)$ & \\
\hline Housewife & $6(13,3)$ & $7(17,9)$ & \\
\hline
\end{tabular}

Table 5. Subject Clinical Manifestation

\begin{tabular}{lc}
\hline Clinical Manifestation & $\mathbf{n}=\mathbf{8 4}$ \\
\hline Nausea & $4(4,8)$ \\
Vomitus & $17(20,2)$ \\
Haematemesis & $13(15,5)$ \\
Recurrent abdominal pain & $50(59,5)$ \\
\hline
\end{tabular}

Table 6. Clinical Manifestation Correlation with H. pylori infection

\begin{tabular}{|c|c|c|c|}
\hline \multirow{2}{*}{ Clinical manifestation } & \multicolumn{2}{|c|}{ H. pylori } & \multirow{2}{*}{$\mathbf{P}$} \\
\hline & Positive (n=45) & Negative $(n=39)$ & \\
\hline \multicolumn{4}{|l|}{ Nausea, n (\%) } \\
\hline Yes & $1(2,2)$ & $3(7,7)$ & $0,333^{2}$ \\
\hline No & $44(97,8)$ & $36(92,3)$ & \\
\hline \multicolumn{4}{|l|}{ Vomitus, n (\%) } \\
\hline Yes & $12(26,7)$ & $5(12,8)$ & $0,115^{b}$ \\
\hline No & $33(73,3)$ & $34(87,2)$ & \\
\hline \multicolumn{4}{|l|}{ Haematemesis, n (\%) } \\
\hline Yes & $6(13,3)$ & $7(17,9)$ & $0,560^{b}$ \\
\hline No & $39(86,7)$ & $32(82,1)$ & \\
\hline \multicolumn{4}{|l|}{ Recurrent abdominal pain, $\mathrm{n}(\%)$} \\
\hline Yes & $26(57,8)$ & $24(61,5)$ & $0,726^{b}$ \\
\hline No & $19(42,2)$ & $15(38,5)$ & \\
\hline
\end{tabular}




\section{Discussion}

H. pylori is a gram-negative bacteria, spiral-shaped, often found on the gastric epithelium surface, and is considered the most common bacterial infection in the world. ${ }^{9} \mathrm{H}$. pylori can colonize in the human gastrointestinal tract and is one of the causes of intestinal and gastric ulcers or one of the factors causing gastric malignancy. ${ }^{10}$ Clinically, all humans infected with this organism can have gastritis symptoms in the form of abdominal pain that can last for years and can develop into chronic inflammation. $H$. pylori infection is known to be associated with various risks of chronic gastritis, peptic ulcer disease (PUD) in the stomach and/ or duodenum, gastric mucosal-associated lymphoid tissue (MALT) lymphoma, and gastric adenocarcinoma. ${ }^{9}$ Gastritis caused by persistent $H$. pylori infection often accompanied by mucosal atrophy or intestinal metaplasia, closely related to gastric cancer development. In the last years, evidence suggests that endoscopy can be used to grade gastric intestinal metaplasia, shifting from random biopsies to "target biopsies" of those areas highly suspicious for intestinal metaplasia and increasing diagnostic accuracy of metaplastic chronic atrophy gastritis. ${ }^{11}$ A recent study validated an endoscopic classification of intestinal metaplasia by endoscopy as compared to histology with promising results. ${ }^{12}$

H. pylori infections, if untreated, remain for the rest of an individual's life. Several data reports that $H$. pylori infection in children is mostly asymptomatic or exhibits non-specific gastrointestinal symptoms. ${ }^{1,13}$ Gastritis often shows recurrent abdominal pain complaints in children, considered by some researchers as a clinical symptom associated with $\mathrm{H}$. pylori infection. It is challenging to distinguish gastritis with $\mathrm{H}$. pylori infection and non-H. pylori infection. The clinical manifestations of Helicobacter pylori infection are: Recurrent abdominal pain (at least once a week), pain in the epigastrial area, frequently vomit, decrease of body weight, growth disorder, iron deficiency anemia, recurrent diarrhea, and malnutrition. ${ }^{1,13}$

Among Asians, H. pylori infection confers a greater than two-fold increased risk for developing gastric cancer. ${ }^{14}$ Several studies have investigated the risk factors associated with H. pylori infection. The major reported risk factors for infection in developing countries are poor socioeconomic conditions and poor hygiene during childhood. Socioeconomic factors associated with lower socioeconomic status, considered to have a higher impact on developing H. pylori infection. Furthermore, there is an inverse relationship between education level and $\mathrm{H}$. pylori infection, it was found that individuals with low education levels have a higher risk than those who have higher education. ${ }^{15}$ Another related factor is residence; those who live in rural areas, crowded homes, and having a source of contaminated drinking water are risk factors for H. pylori infection. ${ }^{16}$

Most of the studies reported no significant difference in H. pylori infection between men and women, both in adults and children. Stephen et al. found there is no significant difference between men and women who were suffering H. pylori gastritis $(\mathrm{p}=0.704){ }^{7}$ Alimohammadi et al. in Iran also found gender did not have a statistical difference $(\mathrm{p}=0.8) .{ }^{17}$ Our study found girls more dominant in the two groups: $71.1 \%$ in group 1 and $61.5 \%$ in group 2, but there is no significant difference between the two groups with $p=0.353$. Hagag et al. in Egypt found the mean age of $\mathrm{H}$. pylori infection $8.5 \pm 1.65$ years, and there is no significant difference between age and $\mathrm{H}$. pylori infection with $\mathrm{p}=0.743 .{ }^{18}$ Our study found age mean $\mathrm{H}$. pylori infection 11.79 years old and there is no significant difference between age and $\mathrm{H}$. pylori infection with $\mathrm{p}=0.594$. The significance of gender and age of $\mathrm{H}$. pylori infection possibly due to differences in geography and minim of sample sizes.Study in Taiwan by Chen at al. found there is no significant difference of body weight and body height between the infection of $\mathrm{H}$. pylori infection with $\mathrm{p}=0.847$ and $\mathrm{p}=0.132 .{ }^{14}$ Our study also found that there is no significant difference of body weight and body height between the infection of $\mathrm{H}$. pylori infection with $\mathrm{p}=0.942$ and $\mathrm{p}=0.892$.

The risk of $\mathrm{H}$. pylori infection was influenced by many factors related to the host-agent-environment factor. ${ }^{5}$ Ethnic is one of the factors that widely research abroad. Prevalence of H. pylori infection to be found higher in certain ethnic like Chinese. Based on migration and transmission theory, H. pylori infection was suspected brought by residents who live in high prevalence to the lower one like a study in Pontianak 2016 found that the prevalence of Chinese higher than Dayaknese related to H. pylori infection. ${ }^{5}$ Uwan et al. also found certain ethnic have some relationship with $\mathrm{H}$. pylori infection with $\mathrm{p}=0.038 .{ }^{19}$ Our study found Bataknese dominantly in the two groups either in group 1 gastritis with $H$. pylori (45.5\%) or group 2 gastritis without $H$. pylori $(38.9 \%)$. Our study also found no significant differences between ethnic and H. pylori infection with $\mathrm{p}=0.485$. Our study's result most likely because the origin ethnic in Medan is Bataknese and due to the lack of the subject number. 
Hasosah et al. in Saudi Arabia found there were positively associated between socioeconomic status and H.pylori infection where the mostly incidence to be found at low socioeconomic status with $\mathrm{p}=0.016{ }^{20}$ Contrary to Hasosah, Chen et al. found that the most cases of $\mathrm{H}$. pylori were founded in good socioeconomic status related with most occupational status of fathers and mothers were private employee, but there was significant difference between socioeconomic status with $\mathrm{p}=0.007 .{ }^{14}$ Our study found that there was no significant difference between father's occupation and mother's occupation with $\mathrm{p}=0.187$. A study in Pontianak by Uwan et al. found there was no significant difference between the educational level with $\mathrm{H}$. pylori infection. Our study in line with Uwan that there was no significant difference between the academic level of children, fathers and mothers with the occurrence of $\mathrm{H}$. pylori infection with $\mathrm{p}=0.893$.

A study in America found that $\mathrm{H}$. pylori infection to be found in low educational level and low socioeconomic levels. Basically, socioeconomic status is not limited to income and social class but must also consider living standards, sanitation, urbanization, and education levels. The high prevalence of H. pylori infection in the group with low education levels is associated with socioeconomic levels, hygiene-sanitation, and high occupancy of living. These conditions can lead to very close contact between individuals and easier transmission of agents' diseases. The level of education of patients with $\mathrm{H}$. pylori infection is more likely to be found at lower levels of education $63.3 \% .^{21}$

Hagag et al. found the most clinical manifestation between the two groups was recurrent abdominal pain $75.3 \%$ in gastritis with $\mathrm{H}$. pylori group and $71.4 \%$ in gastritis without $\mathrm{H}$. pylori group. ${ }^{18}$ Our study found that recurrent abdominal pain was founded in the two groups with $57.8 \%$ in group 1 and $61.5 \%$ in group 2 . Our study in line with study by Ramayanthi et al. and Simadibrata et al. that were gastrointestinal symptoms that similar in children infected with H. pylori and those who are not infected, so H. pylori infection generally does not have distinctive symptoms. ${ }^{22,23}$

The prevalence of infection caused by H. pylori, which is more than $80 \%$, is founded in developing countries. In contrast, it is much lower in industrialized countries, and the prevalence is reported to be steadily decreasing. ${ }^{24,25} \mathrm{H}$. pylori prevalence estimates show a significant variation globally, with rates varying from $15.1 \%$ in developed countries (Australia) to $87.7 \%$ in developing countries (Nigeria). ${ }^{26} \mathrm{H}$. pylori infection that found in early childhood and causes a variety of gastrointestinal and extragastrointestinal diseases. Chronic colonization with H. pylori may significantly increase the risk of gastric adenocarcinoma in children. ${ }^{27}$ Habib et al. in Arab Saudi found that children infected with $\mathrm{H}$. pylori had a more prominent clinical manifestation of upper gastrointestinal as recurrent abdominal pain $(\mathrm{p}<0.001)$, anorexia $(\mathrm{p}<0.001)$, nausea $(\mathrm{p}=0.026)$ compared with children without $\mathrm{H}$. pylori infection. ${ }^{27}$

Our study found that there is no significant relationship between gastritis clinical manifestation with $H$. pylori infection with nausea $(\mathrm{p}=0.333)$, vomitus $(\mathrm{p}=0.115)$, haematemesis $(\mathrm{p}=0.560)$, recurrent abdominal pain $(\mathrm{p}=0.726)$. Our study in line with the theory that $\mathrm{H}$. pylori infection may have unspecific clinical manifestation. ${ }^{28}$

\section{Conclusion}

There are various characteristics of pediatric patients with clinical symptoms of gastritis at Haji Adam Malik General Hospital and educational network hospital. Our study found no significant relationship between children's characteristic and gastritis clinical manifestation with or without H. pylori infection. The majority of clinical manifestation is recurrent abdominal pain, and there is no significant manifestation between gastritis with or without $\mathrm{H}$. pylori infection, so not all children with gastritis needed therapy such as antibiotics and PPI.

\section{Acknowledgments}

I would like to dedicate my gratitude to all the lecturers of Pediatric Department, School of Medicine University of North Sumatera, my family, and my friends for their endless support.

\section{Conflicts of interest}

The author declares that there are no conflicts of interest.

\section{References}

1. Hegar, B. Infeksi Helicobacter Pylori pada Anak.Sari Pediatri.2000;2: 82-89

2. Miftahussurur M, Yamaoka Y. Diagnostic Methods of Helicobacter pylori Infection for Epidemiological Studies: Critical Importance 
of Indirect Test Validation. Biomed Res Int. 2016;2016:4819423.

3. Crowe SE. Helicobacter pylori Infection. N Engl J Med. 2019;380(12):1158-65.

4. Efektivitas Terapi Infeksi Helicobacer Pylori Pada Anak Dengan Keluhan Sakit Perut Berulang Setelah Satu Tahun Terapi Eradikasi. Sari Pediatri. 2013;15:111-15.

5. Uwan WB, Syam AF, Lesmana CRA, Rumende CM. Perbedaan Prevalensi Infeksi Helicobacter pylori antara Etnis Tionghoa dan Dayak dengan Sindrom Dispepsia. Jurnal Penyakit Dalam Indonesia. 2017;3(1).

6. Tussakinah W, Masrul M, Burhan IR. Hubungan Pola Makan dan Tingkat Stres terhadap Kekambuhan Gastritis di Wilayah Kerja Puskesmas Tarok Kota Payakumbuh Tahun 2017. Jurnal Kesehatan Andalas. 2018;7(2).

7. Garna H, Nataprawira HM. Infeksi Helicobacter Pylori. Dalam Pedoman Diagnosis dan Terapi Ilmu Kesehatan Anak.

Departemen/SMF Ilmu Kesehatan Anak Fakultas Kedokteran Universitas Padjajaran Dr.Hasan Sadikin. Bandung. 2015;(5): 315-6

8. Hasosah M, Satti M, Shehzad A, Alsahafi A, Sukkar G, Alzaben A, et al. Prevalence and risk factors of Helicobacter pylori infection in Saudi children: a three-year prospective controlled study. Helicobacter. 2015;20(1):56-63.

9. Olokoba A, Bojuwoye M, Obateru O. Helicobacter Pylori Eradication Therapy: A Review of Current Trends . Niger Med J.

2013;54(1):1

10. Manfredi M, Gaiani F, Kayali S,Bizzarri B, Iuliano S, Minelli R. How and When Investigating and Treating Helicobacter Pylori

Infection in Children. Acta Biomed. 2018;89(8-S):65-71.

11. Lahner E, Zagari RM, Zullo A, Di Sabatino A, Meggio A, Cesaro P, et al. Chronic atrophic gastritis: Natural history, diagnosis and therapeutic management. A position paper by the Italian Society of Hospital Gastroenterologists and Digestive Endoscopists [AIGO], the Italian Society of Digestive Endoscopy [SIED], the Italian Society of Gastroenterology [SIGE], and the Italian Society of InternalMedicine [SIMI]. Dig Liver Dis. 2019;51(12):1621-32.

12. Esposito G, Pimentel-Nunes P, Angeletti S, Castro R, Libanio D, Galli G, et al. Endoscopic grading of gastric intestinal metaplasia (EGGIM): a multicenter validation study. Endoscopy. 2019;51(6):515-21.

13. Suerbaum Sebastian., Pierre Michetti. Helicobacter Pylori Infections. New English J Med. 2002;347(15):1175-1186.

14. Chen HL, Chen MJ, Shih SC, Wang HY, Lin IT, Bair MJ. Socioeconomic status, personal habits, and prevalence of Helicobacter pylori infection in the inhabitants of Lanyu. J Formos Med Assoc. 2014;113(5):278-83.

15. Kuipers EJ, Looman CWN, Ouwendijk M, van Blankenstein M, van Vuuren AJ. The Prevalence of Helicobacter Pylori Infection in The Netherlands. Scand J Gastroenterol. 2013;48(7):794-800

16. Eusebi LH, Zagari RM, Bazzoli F. Epidemiology of Helicobacter Pylori Infection. Helicobacter. 2014;19(S1):1-5.

17. Alimohammadi H, Fouladi N, Salehzadeh F, Alipour SA, Javadi MS. Childhood recurrent abdominal pain and Helicobacter pylori infection, Islamic Republic of Iran. East Mediterr Health J. 2017;22(12):860-4.

18. Hagag AA, Amin SM, Emara MH, Abo-Resha SE. Gastric Mucosal Oxidative Stress Markers in Children with Helicobacter Pylori Infection. Infect Disord Drug Targets. 2018;18(1):60-7.

19. Uwan WB, Syam AF, Lesmana CRA, Rumende CM. Perbedaan Prevalensi Infeksi Helicobacter pylori antara Etnis Tionghoa dan Dayak dengan Sindrom Dispepsia. Jurnal Penyakit Dalam Indonesia. 2017;3(1).

20. Hasosah M, Satti M, Shehzad A, Alsahafi A, Sukkar G, Alzaben A, et al. Prevalence and risk factors of Helicobacter pylori infection in Saudi children: a three-year prospective controlled study. Helicobacter. 2015;20(1):56-63.

21. Fiedorek MD, Malaty HM, Evans DL, Phumphrey CL, Casteel HB, EvansJr DJ et all. Factors Influencing the Epidemology of Helicobacter Pylori infection in children. Pediatrics. 1991;88:578-82

22. Ramayanthi T, Prasetyo D, Garna H. Efektivitas Terapi Infeksi Helicobacter Pylori pada Anak dengan Keluhan Sakit Perut Berulang Setelah Satu Tahun Terapi Eradikasi. Sari Pediatr. 2017;15(2):111.

23. Simadibrata MK, Makmun D, Abdullah M, Syam AF, Fauzi A, Renaldi K, et al. Diagnosis Infeksi Helicobacter pylori. Dalam Konsensus Nasional Penatalaksanaan Dispepsia dan Infeksi Helicobacter pylori. Jakarta. 2014. p.1-16

24. Moosazadeh M, Lankarani KB, Afshari M. Meta-Analysis of The Prevalence of Helicobacter Pylori Infection Among Children and Adults of Iran. Int J Prev Med. 2016;MARCH-2016:6-11.

25. Björnsson ES, Asgeirsdottir GA, Hreinsson JP, Olafsdottir AS, Hrafnkelsson H. Helicobacter Pylori Infection In Icelandic Children . Scand J Gastroenterol. 2017;52(6-7):686-690.

26. Hooi JKY, Lai WY, Ng WK, Suen MMY, Underwood FE, Tanyingoh D, et al. Global Prevalence of Helicobacter pylori Infection: Systematic Review and Meta-Analysis. Gastroenterology. 2017;153(2):420-9.A

27. Habib HS, Hegazi MA, Murad HA, Amir EM, Halawa TF, El-Deek BS. Unique features and risk factors of Helicobacter pylori infection at the main children's intermediate school in Rabigh, Saudi Arabia. Indian J Gastroenterol. 2014;33(4):375-82.

28. Zamani M, Ebrahimtabar F, Zamani V, Miller WH, Alizadeh-Navaei R, Shokri-Shirvani J, et al. Systematic review with metaanalysis: the worldwide prevalence of Helicobacter pylori infection. Aliment Pharmacol Ther. 2018;47(7):868-76. 